\title{
A holdvilág ezüstjétől az érzékeny ezüstszemcsékig
}

A fotográfia szép története és a későromantikus hagyomány*

Nádas Péter A fotográfia szép története címü műve, amely elöször 1993-ban jelent meg a Filmvilágban mint Monory M. András készülő filmjének alapanyaga, ${ }^{1}$ mintegy az Emlékiratok könyvét írja tovább, ahogy erre Balassa Péter több alkalommal is figyelmeztet. ${ }^{2}$ Balassa monográfiájának vonatkozó fejezete, amely tudtommal mindmáig a mü egyetlen alaposabb elemzése, nemcsak a „kellékek”, azaz a Thoenissen-történet nagypolgári, dekadens légkörének átvételét, hanem fontos motivikus átfedéseket is észlel. ${ }^{3}$ Így például felfigyel a Narcissus-mítoszra történő finom utalásra, ${ }^{4}$ amely a nagyregény elemzésében a lacani diskurzushoz, a tükör-stádiumhoz való kapcsolatot tette lehetövé. ${ }^{5}$ A fotográfia szép történetében a szerelmi háromszög sok tekintetben ismétli az Emlékiratok könyvének szereplői viszonyait; a hármas kompozíció nemcsak a Gyllenborgfényképet, hanem a nagyregény számos más vonatkozását idézi; ${ }^{6}$ még akkor is, ha a filmnovella intertextuális utalásrendszere egy másik hármas viszonyrendszert nevez meg forrásául, méghozzá Helen Hessel életrajzi műveiből - vagy akár a filmvászonról - ismert, korántsem szokványos szerelmi háromszöget.?

\footnotetext{
“A tanulmány elkészültéhez az Általános Irodalomtudományi Kutatócsoport „Kultúraalkotó médiumok, gyakorlatok és technikák. A rögzített nyelv használata a tudományban és az irodalomban” címü, az MTA Támogatott Kutatócsoportok Irodája által finanszírozott projektje nyújtott segítséget. ${ }^{1}$ Lásd Filmvilág, 1993/8, 8-23; illetve Filmvilág, 1993/9, 36-51. A filmnovellából végül nem készült film.

${ }^{2}$ Vö. Balassa Péter, Nádas Péter, Pozsony, Kalligram, 1997, 473-483. Olyannyira, hogy Czigány Ákos épp ezen a példán mutatja be Balassa könyvének „nárcisztikusságát”, amely az összes művet a nagyregény felől közelíti meg. Lásd Czigány Ákos, Esszéktöl északra (Balassa Péter: Nádas Péter), Jelenkor, 1998/6, 672-673.

${ }^{3}$ Több helyen nemcsak motivikus, hanem szövegszerü átvételek is erősítik, hogy a filmnovellát az Emlékiratok könyve felől, mintegy „hipertextusaként” olvassuk. Lásd például az antik falikép fejezetében kiemelt helyen szereplő „mélyzöld homály” (NÁDAs Péter, Emlékiratok könyve, I. kötet, Pécs, Jelenkor, 353.) kifejezését, amely A fotográfia szép történetében, bár talán nem olyan hangsúlyos helyen, szintén előkerül. NÁDAs Péter, A fotográfia szép története = N. P., Vonulás: Két filmnovella, Pécs, Jelenkor, 2001, 118.

${ }^{4}$ Kornélia és Carl nézik magukat egy „tóká”-ban: „Elérik egymás kezét a víz felett, s egyensúlyukat veszítve loccsannak bele. A hang és a kép most sem találkozhatik. Elébb a kéj rettenetének, majd a rettenet kéjének ordításai." NádAs, A fotográfia..., i. m., 144. Az égi és a földi szerelemröl nagyszabású Ovidius-olvasata ismeretében (amely megírása és a filmnovella születése között feltehetően igen csekély az időbeli távolság) továbbgondolható a párhuzam; Kornélia és Carl ez esetben a Narcissus-történet modern újraírásának hösei volnának, akik tragédiája immár nem (víztükör-)kép és hang, hanem fényképes rögzítés és írás öszszeegyeztethetetlenségéből fakadna.

${ }^{5}$ Balassa, i. m., 473.

${ }^{6}$ Vö. Az égi és a földi szerelemről autóbusz-példázatával: „A másik személy emberi minőségének értékeléséhez azonban mindig egy olyan harmadik személy virtuális jelenlétére volt szükségük, akiről mindkettőjüknek volt véleménye." NÁDAs Péter, Az égi és a földi szerelemről, Bp., Szépirodalmi, 1991, 37.

${ }^{7}$ A fotográfia szép története első oldalán közli a felhasznált, idézett szerzők listáját, amelyen szerepel Helen
} 
A fotográfia szép történetében azonban az én hasadtsága nem az emlékiratok öszszerendezhetetlenségének, megírhatatlanságának kudarcában, mint inkább a főhősnő őrületében, pontosabban az őrület nyomán a (kül-)világ torzuló, elbizonytalanodó érzékelésében artikulálódik. Kornélia őrülete ugyanakkor mintha fotográfiai célkitüzéseiből, illetve ezek kudarcából eredne. ${ }^{8}$

A főhősnő története a sokatmondó Lelkében felemelkedik című fejezettel kezdődik, melyben a léggömb jelképiségét a „pattanásig feszülo"” idegek és a kötélzet közötti párhuzam is aláhúzza. ${ }^{9}$ A léggömb a lélek testtől („a testem börtön”, mondja Kornélia Károlynak) - a haszontalan „kéj” fogságábó ${ }^{10}$ - való elszakadást ígéri. ${ }^{11} \mathrm{~A}$ léghajózás férfias vállalkozásában (Kornélia is „kifejezetten férfiasan van öltözve” ${ }^{12}$ ) mintha kettéválna Kornélia és a mérnök szándéka. A mérnök, akinek tudományos eltökéltsége igen jól illeszkedik a novella történeti díszleteihez, „gyüjt”, „összevet” és „kimér”, míg Kornélia célja, aki ezen eljárásban a „törvényt” és az „Istent” hiányolja: „[e]gyre magasabbra, egyre távolabbra. Ne legyen mondat, érzés, mozdulat, melyre ne néznénk alá a madarak távlatából." ${ }^{13}$ Mindkettejük érdeklődésében közös és jellegzetes a világra vetett tekintet. A léggömb esélyt ad arra, hogy fentről „mindent” lássanak; a repülés egy külső, totális nézőpont, a megvalósult „descartes-i optika” ígérete. Ez a látószög, amely itt a testtől való elszakadás iránti reménytelen vágyakozás manifesztációja, tulajdonképpen a hagyományos realista irodalom narratív alaptechnikája is, amely a filmnovella fiktív történetiségével egy időben, a fotográfia technikájától valószínűleg nem függetlenül ${ }^{14}$ alakult ki.

Ezen a ponton válik különösen jelentésessé, hogy a léghajóutazás, de voltaképpen

Hessel; a filmnovellával egy évben készült el Nádas Helen című esszéje, amelyben Hessel életével és annak jelentőségével foglalkozik (NÁdas Péter, Helen = N. P., Esszék, Pécs, Jelenkor, 2001, 194-221.). Az életrajz - pontosabban Henri-Pierre Roché önéletrajzi regényének - felhasználásával François Truffaut rendezett filmet (Jules et Jim, 1962).

${ }^{8}$ A primárius, tudjuk meg, éppen a főhősnő elméjének épségét megőrzendő kobozza el az „apparátust”: „Kihasználtam gyöngeségét, bizony elkoboztattam az apparátusát. Ne is reménykedjen semmiben. Se a szörnyü Henriette, se az édes kis Milena nem árulja el, hogy hová, milyen titkos faliszekrénybe rejtettük el. Kevesebbtől nem is lett volna érdemes megfosztani. Arra ítélem, hogy két szép szemével nézzen, s amit lát, az ujjacskáival tapintsa. Ha akarja." NÁDAs, A fotográfia..., i. m., 148.

${ }^{9}$ Uo., 101.

${ }^{10}$ Nem túl finoman utalva az onánia már az Emlékiratok könyve kapcsán is említett motívumára: „[c]sak a saját faszomba kapaszkodhatom." Uo., 102.

${ }^{11}$ Uo., 113.

${ }^{12} \mathrm{Uo}$.

${ }^{13}$ Uo., $107,104$.

${ }^{14}$ A fotográfia szerepéről a realista látásmódban legrészletesebben lásd Rolf H. KRAuss, Photographie und Literatur: Zur photographischen Wahrnehmung in der deutschsprachigen Literatur des neunzehnten Jahrhunderts, Ostfildern, Hatje Cantz, 2000; Philippe OrTel, La littérature à lère de la photographie: Enquête sur une révolution invisible, Nîmes, Jacqueline Chambon, 2002, 171-190; valamint egy némileg más megközelítésmóddal dolgozó átfogó munkát, Irene Albers, Sehen und wissen: Das Photographische im Romanwerk Émile Zolas, München, Fink, 2002. 
A fotográfia szép történetének egésze Adalbert Stifter 1840-es A kondor című elbeszélésének újraírása, vagy, követve a müfajválasztás intencióit, „megfilmesítése”. ${ }^{15} A$ kondort - anélkül, hogy ezzel a különös elbeszélés részletesebb elemzésébe bocsátkoznék - szintén a „madárperspektíva” szervezi: nemcsak Cornelia ${ }^{16}$ nézhet le a földre a léghajóról, Gustav is felülről figyeli a várost, és ezt rögzíti a szöveg zárlatában a Párizsban kiállított képek egyike is: „nagy város képe, felülről látva - házak tornyok, templomok tömegével a holdvilágban úszva". ${ }^{17}$ Gustav is felülről lát rá a városra, mint Cornelia, ugyanakkor tekintetük mintegy keresztezi is egymást, amennyiben Gustav, legalábbis a bevezető Éjjeli kép tanúsága szerint, inkább a holdat, majd, miután feltűnt a láthatáron, a léghajót fürkészi. Vagyis felfelé, a messzeségbe tekint, míg Cornelia „egyenesen a levegős mélységbe”, a földre néz, „hogy nem talál-e ismerős helyet”. ${ }^{18}$ A két tekintet így egymás tükörképévé válik, amelyek kölcsönös kudarcban metszik egymást: Gustav éppúgy nem tudja befogni tekintetével a messzeséget, ahogy Cornelia megszédül a - számára adott - távolság tapasztalatától. Az elbeszélés erre a komplementer, mégis szubverzív ellentétezésre épül, amelyet az éles időbeli, de még inkább fokalizációs elbeszélői váltások tesznek hangsúlyossá:; ${ }^{19}$ Gustav égiteste a Hold, amely bevilágítja az éjszakát (a záró fejezet a két festményt „holdképnek" ${ }^{20}$ nevezi), és apró esti fényekkel - a szegény mosónő, illetve a festő lámpájával ${ }^{21}$ - lép párbeszédbe, miként az én-elbeszélő Gustav a „becsületes, jón ${ }^{22}$ kandúrral. Amikor feltünik a léghajó, mint egy „gondolatjel az égen”, ${ }^{23}$ mintegy felülírja a holdvilágot; az éj nappalba fordul, a szöveg pedig elhagyja Gustav én-elbeszélését, vagyis a „naplót”, amelyből „az előbbi rész szóról szóra van véve”, ${ }^{24}$ hogy a léghajó belsejéből közvetíthessen. Cornelia így már a Naphoz kerül közel, amely azonban érezhetően a megrettenő nő látószögéből tárul fel: „és végre a nap fenyegető égitestnek, kivágott korongnak, hullámzó, fehérré olvadt fémnek látszott, sugarak és melegség nélkül: így bámult megsemmisítő fényével az örvényből - anélkül, hogy akár egy kicsiny fényt is megörzött volna ezekben az üres terekben; csak a ballonra és a hajóra meredt

\footnotetext{
${ }^{15}$ A Stifter-intertextus lokalizálásáért Kelemen Pálnak tartozom köszönettel.

${ }^{16}$ A következőkben Stifter elbeszélésére utalva a német eredeti írásmódját követem, amikor a női föszereplöre hivatkozom, így megkülönböztetve $A$ fotográfia szép története Kornéliájától.

${ }^{17}$ Adalbert Stifter, A kondor, ford. Benedek Károly, Bp., Franklin, 1907, 34.

${ }^{18}$ Uo., 14-15.

${ }^{19}$ Vö. Michael WiLd, Wiederholung und Variation im Werk Adalbert Stifters, Würzburg, Königshausen und Neumann, 2001, 21-34. Az egymást kiegészítő ellentételekre épülő szöveg kapcsán joggal merül fel az a lehetőség, hogy a bonyodalmat a társadalmi nemi szerepek feszültségeként értelmezzük, azaz Cornelia női szerepéből való kitörésére való törekvés és kudarc történeteként olvassuk az elbeszélést. Vö. Sabine SснміDт, Das domestizierte Subjekt: Subjektkonstitution und Genderdiskurs in ausgewählten Werken Adalbert Stifters, St. Ingbert, Rührig Universitätsverlag, 2004, 104-130.

${ }^{20}$ Stifter, A kondor, i. m., 34.

${ }^{21}$ Uo., 6.

${ }^{22}$ Uo., 35.

${ }^{23}$ Uo., 8.

${ }^{24}$ Uo., 10.
} 
egy éles fény, amely kísértetszerűen emelte ki a gépet az őt körülvevő éjszakából és az arcokat halottakéhoz hasonlóra rajzolta, mint egy laterna magicában". ${ }^{25} \mathrm{~A}$ fényképtechnika feltalálásával gyakorlatilag egy időben született szöveg az idegen(-szerü) élményeként, a „halál hírnökeként” idézi meg a laterna magicát, ezt azonban nem elsősorban a légballon-utazás technikai-mérnöki kontextusa, mint inkább Cornelia „férfias” törekvésének, világmegismerő vágyának kudarca hívja elő, amelyet, mintegy újraírva az Ikarosz-mítoszt, az éltető nap önmagából kifordulása, kiüresedése és halálos fenyegetéssé alakulása jelképez. A laterna magica-szerü nap és a holdvilágos éjszaka - amelyek a szöveg „fényviszonyait” szervezik, valamint párbeszédbe lépnek a romantika hagyományának képi világával ${ }^{26}$ - motívumának központi szerepe azonban meginog: az elbeszélői hang markáns jelenléte és a hangsúlyosan perspektivikus szerkesztés elbizonytalanítják a romantikus kép stabilizálódását.

Ezzel párhuzamosan a szerelmi szál erőteljes temporális indexet kap a csók pillanatnyiságában: „két emberélet legboldogabb pillanata megérkezett és - elmult”. ${ }^{27} \mathrm{Ez}$ a temporalitás íródik be Gustav két festményének esztétikájába is; a holdvilágos látképek az elmúlt szerelemre emlékeztetnek, amelyet érdekes módon a beszédszerűség, a hang metaforikája jelenít meg: „Hogy érezte agyában ez ártatlan, szemérmes képnek csillogását, mint egy lélek csendes szemrehányásait, melyek most hallgatnak, de mégis mint fénysugarak beszélnek, melyek mélyebbre hatnak, melyek mindig itt vannak, mindig világítanak és soha el nem hallgatnak, mint a hang." ${ }^{{ }^{28}} \mathrm{~A}$ kondor zárlata így kevésbé a romantikus szerelemideál beteljesülését, mint inkább a romantikus elvágyódás képi rögzíthetöségét kérdőjelezi meg, ahol a „kép” nem csupán a festményre, hanem önreflexív módon az elbeszélés képiségére, a „láttatás” lehetőségeire is vonatkozhat; a kép szimbolikus állandóságának helyébe az elmúlt visszaállíthatatlanságának, vagyis az ezt megkísérlő reprezentációk szükségszerü tökéletlenségének, a „megtörtént hatalmának”29 tapasztalata lép.

A fotográfia szép története tehát nemcsak A kondor cselekményének fö mozzanata-

\footnotetext{
${ }^{25}$ Uo., 17. A fordítást jelentős mértékben módosítottam, ugyanis a kissé idejétmúlt, de többé-kevésbé megbízható magyar szöveg itt az egyszerüsítés mellett mintha tudatosan „lágyítaná” Stifter megfogalmazását: egyfelől megőrzi a napot alanynak ott, ahol pedig az eredeti már egy (kísérteties hangulatú, éppen ezért) nehezebben meghatározható forrásból érkező fényről beszél, másfelől egész egyszerűen nem említi az „üres tereket” („wesenlosen Räumen”), a halottakra történő utalást („totenartig zeichnend”), valamint - az éppen a fényforrás elmozdulása miatt lényeges - „laterna magica”-hasonlatot. Vö. Adalbert StIFTER, Der Kondor = A. S., Gesammelte Erzählungen I., hg. Walter Hoyer, Leipzig, Dieterich'schen Verlagsbuchhandlung, 1954, 19.

${ }^{26}$ WILD, i. m., 33. A romantikus költészet „fényviszonyairól” a technikai médiumok megjelenése felől lásd KéKEsI Zoltán, Mint hír a dróton (Babits: Mozgófénykép; Kassák: Utazás a végtelenbe) = Induló modernség - Kezdödö avantgárd, szerk. Bednanics Gábor, Eisemann György, Bp., Ráció, 2006, 264-275.

${ }^{27}$ Stifter, A kondor, i. m., 27.

${ }^{28}$ Uo., 35.

${ }^{29}$ A magyar fordítás („Nyugodtan és hidegen állt lelke előtt a tények hatalma, mely soha, de már soha meg nem változtatható”, Uo., 36.) némileg önkényesen „tényekként” adja vissza az eredeti „Geschehenen” kifejezést. Vö. Stifter, Der Kondor, i. m., 32.
} 
it veszi át, hanem bizonyos tekintetben prózapoétikai sajátosságait is továbbírja. A filmnovellát egyfelől jellemzi a töredékes, elliptikus szerkesztésmód, amelyet Balassa Péter elemzése a szöveg (fény)képszerűségeként azonosít és a fotográfia metaforáját kiaknázva igen részletesen be is mutat, ${ }^{30}$ másfelöl, ezzel szoros összefüggésben, sajátszerüvé teszi a nyelvi referencialitás és a narrátori autonómia elbizonytalanítása is. Nem világos, hol kezdődnek Kornélia képzelgései, akinek a képzelete az orvos szerint „oly nagyra nőtt, hogy maga [...] sem tudhat[ja], mi történik vele [...] valóságosan”; ${ }^{31}$ Károly-Karol-Carl kiléte zavaros, ${ }^{32}$ éppúgy, mint a „sebesült erdészé”, aki többször előbukkan a szövegben talán ő az, akinek megsebesítését társai az első csoportképen tettetik. ${ }^{33} \mathrm{~A}$ filmnovella eseményszála legalább három sík, három narratív struktúra között modulál: a figurák párbeszédének tere folyamatosan (leírásokon keresztül hozzáférhetö) fényképekké alakul, a képek ugyanakkor megelevenednek. Mindez kiegészül egy „imaginárius film” síkjával is, amennyiben például a narrátori „hangok” - néha nehezen beazonosíthatóan - szétválnak „hallhatơ" narrációvá, illetve (az el nem készült filmen) „látható”, azaz tulajdonképpen „rendezői utasítások”-ként funkcionáló részekké, amely utóbbiak néha épp a hang és a kép szétcsúszására figyelmeztetnek. Ugyanakkor egyes mondatok (mint például a többször visszatérő „Van egy hang”) ellenállnak e forgatókönyvet imitáló szerkezetnek.

Az elbeszélés tehát nem tárulkozik fel az olvasói tekintetnek, ahogy a léghajó-út is kudarcba fullad. A veszélyes kísérlet eredménye csupán „szellemalakok, látomás”; ${ }^{34}$ a fényképezés technikája nem a mérnök és az orvos racionális megfontolásaihoz, hanem a főhősnő képzelődéseihez kapcsolódik. Kornélia az általa „látottakat” kívánja rögzíteni (az apparát elkobzása után fejben ${ }^{35}$ ), amely látás tehát imaginációként, képzelődésként értendő; az orvos éppen azt akarja elérni, hogy ehelyett „a két szép szemével” nézzen. ${ }^{36}$ Kornélia azonban nem jár sikerrel: „Mert a sötétség a fényt nem fogadja be. A kép ezt írja ki. Hol sötétségbe lök, hol fényre hoz. A kép megtart. Minden mindig megváltozik. Ezt a szörnyüséget nem lehet elviselni." ${ }^{37}$

A fénykép megtart, az ábrázoltak változását, az idő folyását nem képes rögzíteni, bár

\footnotetext{
${ }^{30}$ BALASSA, i. m., 473-483, különösen 474.

${ }^{31}$ NÁdAs, A fotográfia..., i. m., 140.

${ }^{32}$ A halottnak hitt Károly különös díszletek között, egy temetőben tűnik fel, majd megjelenik a rá megszólalásig hasonlító Carl (Uo., 146.) - a névváltozatok, amelyek variálódását a szöveg egyik dialógusa külön hangsúlyozza („Miért nem mondta ki soha a valódi nevem?”, Uo., 139.), akár a Kornélia név variációiként is érthetök.

${ }^{33}$ „Egyikük hanyatt fekszik a ledöntött törzsön, a másik kettő úgy tesz, mintha nagy komoly ábrázattal a derekánál fürészelné el emezt, ő meg úgy, mintha kínok kínját kéne kiállnia, a többiek viszont mindeközben a lencsébe vigyorognak.”; később azonban két alkalommal is „sebesült erdész”-ről van szó. Uo., 126, 168, 176. ${ }^{34}$ Uo., 110.

${ }^{35} \mathrm{~A}$ „fejben fényképezéshez" lásd a jóval később íródott, Világló részletek című esszé agg mesterét, Akahitot, aki „immár évtizedek óta kizárólag az agytörzsére fényképezett”. NÁDAs Péter, Világló részletek, Új Forrás, 2010/9, 4 .

${ }^{36}$ NÁdAs, A fotográfia..., i. m., 150, 147-148.

${ }^{37}$ Uo., 121.
} 
Kornélia tervét nem adja fel: „Ha legalább három órán át nyitva tartom, akkor nemcsak a hold fényét rögzíti, hanem a fény útját az idővel. Valami olyasmit, ami szabad szemmel nem látható. És akkor megint van egy bizonyítékom." ${ }^{38} \mathrm{Ez}$ a bizonyíték azt igazolná, hogy Kornélia víziói valósak, azt, hogy léteznek „képek” a primárius által kizárólagossá tett érzékszervi percepció ${ }^{39}$ és a nyelv értelemadó utólagossága között, amelyet az író Carl védelmez a főhősnővel szemben.$^{40}$ Kornélia számára a fénykép mutat, jelent valamit (ezt a primáriussal szemben kell hangsúlyoznia ${ }^{41}$ ), mégsem nyelvként, szimbólumként müködik, „valamiképpen közös természetü azzal, amit ábrázol”."2 Roland Barthes ugyan határozottan fényképek nézőjeként, nem készítőjeként nyilatkozik, megfigyeléseit összegezve a fotót „őrült igazságként” jellemzi, amely akkor őrült, „ha realizmusa teljes, ha szabad így mondani: eredendő, ha riadt tudatunkba az Idő fogalmát hozza vissza". ${ }^{43}$ Kornélia fényképektől, fényképezéstől nem leválasztható őrületében mintha felismerhetővé válna Barthes gondolatmenete. A párhuzam azonban szükségképp csak érintőleges: Barthes esszéjében az „örület” említése ugyan egyáltalán nem meglepő, mégis inkább marginális, csak nyomatékosítja a vázolt, alapvetően episztemológiai problémát (a tekintélyes Barthes-recepcióban sem gyakran fordul elö, hogy a Világoskamrát kifejezetten a zavar, megbomlás, kétségbeesés dokumentumaként olvassák). A fotográfia szép történetében azonban tulajdonképpen Kornélia őrülete határozza meg a világhoz való hozzáférés feltételeit; a szöveg referencialitásának bizonytalanságai, a fénykép-, álom- illetve fantázialeírások rétegzettsége mind a megbomlott elme müködéseként értelmezhető.

A fényképek, a barthes-i ez volt noéma értelmében csak a már elmúltat, az elmúlást ábrázolhatják - a "Halál ügynökei”, ${ }^{4}$ amely metafora jelen esetben mintegy kibontja Stifter megidézett elbeszélésének kísérteties laterna magica-hasonlatát. Kornélia utolsó fotójával a halált (Carl halálát) rögzíti, akárcsak a novella elején szereplő férfi, aki tulajdonképpen ugyanazon az úton, a szerelem és a halál stációin keresztül jut el e felvételig,

\footnotetext{
${ }^{38}$ Uo., 171. - A Hold fényképezésének tudomány- és kultúrtörténetéhez lásd Carol Armstrong, Der Mond als Fotografie $=$ Diskurse der Fotografie: Fotokritik am Ende des fotografischen Zeitalters, Bd. 2, hg. Herta Wolf, Frankfurt am Main, Suhrkamp, 2003, 359-384.

${ }^{39}$ „Arra itélem, hogy két szép szemével nézzen, s amit lát, az ujjacskáival tapintsa. Ha akarja. Vagy akár az ajkával, a nyelvével is. Ha akarja. Érezze, hogy mindent megtehet. Ha akarja. Még az is a hatalmában áll, hogy ne akarja. Ez lenne a szabadság íze, Kornélia." NÁdAs, A fotográfia..., i. m., 147-148.

${ }^{40}$ „Én a szavakhoz érzéseket társítok, s csak aztán az érzésekhez a képeket.” Uo., 171. Nem véletlen, hogy Kornélia kísérletét Carl megszakításokkal hajtja végre, így az éjszaka egységét megörökíteni hivatott felvétel egymásra fotografált szegmensek halmazaként valósul meg: „Arra gondoltam, hogy az időt helyesebb lenne fázisokra bontani, s ezért félóránként kinyitottam és bezártam. Így talán jobban láthatóvá lesz, ami annyira a lelkén feküdt. De még ezzel sem voltam egészen elégedett, mert amikor felkelt a nap, teljesen önállósítottam magam, s rövid időre ismét megnyitottam." Uo., 175.

${ }^{41}$ „Téved. Ha nem leplezi, akkor ezzel, ha fedezékbe vonul, akkor azzal árulkodik. Olyan képek nincsenek, amelyek semmit nem mutatnak." Uo., 131.

${ }^{42}$ Roland Barthes, Világoskamra: Jegyzetek a fotográfiáról, ford. Ferch Magda, Bp., Európa, 2000, 80.

${ }^{43}$ Uo., $117,123$.

${ }^{44}$ Uo., 81, 96.
} 
mint Kornélia. A férfi története kerettörténet: a záró fejezetben Kornélia jégbe fagyott tetemét kiemelő helikopter (mintegy profanizált „kondor”) nyitja az elbeszélést, antropomorfizált tekintete (amely a léggömbből vizsgálódó Kornélia perspektíváját előlegezi) mintegy keresi a férfit, „kit sikerülhetne megragadnia”, ${ }^{5}$ másrészt megismétli-elörevetíti Kornélia tragédiáját. A főhősnő jégbe fagyott teste talán nem marad fenn az örökkévalónak (hiszen „a jég vészesen csöpög” ${ }^{46}$ ), törekvése, vágya, vagyis „őrülete” állandónak mutatkozik, amennyiben megismétlődik, ${ }^{47}$ mintegy újjászületik a férfi sorsában.

A férfi, aki padlásszobájában készül önmaga halálát, „saját sötétségét" ${ }^{8}$ lefényképezni, A kondor Gustavjának alakmása. A festő az „éjjeli csendet” várja, amikor elül a város, a "kellemetlen esti embertömeg”" ${ }^{2}$ zaja, amikor az ezüstös hold látványa veszi át a hatalmat: „A hold végre felemelkedett a tetők fölé és a magas kékben csillogott, fénylett és csillámlott és az egész égen szerte áradt a világosság, az összes felhőkből ezüst ragyogott [...]" ${ }^{50}$ - ez az a látvány, amelyet a két festmény, Gustav „holdképei” az elbeszélés végén megjelenítenek. Nádas filmnovellájában a fényképész „belso”” hangzavarral küzd: „Arra az órára, percre vártam, melyben elhalnak bennem végre a csatázó szavak, a mondatok többé nem zúgnak és nem zenélnek, nem beszélek és nem beszélnek és nem beszél, se Istennel, se Isten, se szerelmesemmel, se szerelmesem, mikor senki, mikor csak kép marad."51 A férfi monológja nem csupán határozottan „belsővé” teszi a Gustavot zavaró zajt és nyomatékosítja hang és kép ellentétét, de mintegy vitát is folytat a festővel: tagadja Istennel és a szerelmessel való párbeszédet, vagyis tulajdonképpen azt, ami Gustav számára a holdvilág, majd a pirkadati léghajó képében reményt ad. Mindeközben a holdfény ezüstje, amelyet $A$ kondor leírása többszörösen kiemel, a filmnovellában a fotográfia fényérzékeny rétegének ezüstötvözetébe vált: „Jómagam a pirkadatra vártam, de képzeletemet nem tudtam csillapítani. Jön a pirkadat, magasan áll a hold, érzékeny ezüstszemcsék rögzítik földi árnyamat." ${ }^{52} \mathrm{~A}$ fénykép a romantikus kép helyébe lép; az elvágyódás immár nem egy holdvilágos tájkép jelképiségében jelenik meg, hanem a fotográfia magát az elmúlást rögzíti. Gustav tájképeit, amint

\footnotetext{
${ }^{45}$ NÁDAs, A fotográfia..., i. m., 97.

${ }^{46}$ Uo., 192.

${ }^{47} \mathrm{Ez}$ az ismétlés körkörössé teszi az elbeszélést, egyfajta freudi ismétlési kényszert imitálva, amelyről - más kontextusban - Balassa is beszél (BALAssA, i. m., 480.: „És éppen a rögzítés ismétléskényszere az, ami ennek az időtlenító és elkerülhetetlen akarásnak az illuzórikusságát leplezi le.”), és amely Lacan tuché-vel kapcsolatos fejtegetéseinek is alapja (Jacques LACAN, Les quatre concepts fondamentaux de la psychanalyse, Paris, Seuil, 1973, 66.). Az ismétlést a kultúra „örömelv” által uralt szimbolikus mezejéről való kitörés, jelen esetben a rögzítés, a fénykép valósága utáni vágyakozás kényszeríti ki, amelyet Freud halálösztönnek (Todestrieb) nevez. Sigmund Freud, A halálösztön és az életösztönök, ford. Kovács Vilma, Bp., Múzsák, 1991; vö. BARTHES, i. m., 96.

${ }^{48}$ NÁdAs, A fotográfia..., i. m., 99.

${ }^{49}$ Stifter, A kondor, i. m., 5.

${ }^{50} \mathrm{Uo}$.

${ }^{51}$ NÁdAs, A fotográfia..., i. m., 98.

${ }^{52}$ Uo., 101.
} 
azt Stifter elbeszélése világossá teszi, szintén az elvágyódás, a be nem teljesült szerelem (jel)képiesülése teszi széppé; a fotográfia ellenben (és talán ebben áll „szép története”), amikor magát a halált - vagy, mint Kornélia esetében, a hold útját az égbolton - akarja képpé tenni, nemcsak továbbírja a romantikus hagyományt, hanem tagadja is: az elmúlás eseményszerűségét, időbeliségét teszi láthatóvá, vagyis csak a megörökítés, a kimerevítés, a képpé válás lehetetlenségét rögzítheti. A folyamatos elmozdulás (Kornélia és a férfi fotográfiája is "bemozdul” " ${ }^{3}$ ) ebben az értelemben vett „szépsége” így kapcsolódik a „szabálytalanság”, „betegség” Emlékiratok könyvében megismert esztétikájához. ${ }^{54}$

\section{TAMÁs LÉNÁRT}

Der Silberrauch des Mondlichtes und die empfindlichen Silberkörnchen der Fotografie. Péter Nádas' Die schöne Geschichte der Fotografie und die spätromantische Tradition

Die Studie befasst sich mit einem der weniger bekannten Texten von Péter Nádas, Die schöne Geschichte der Fotografie unter intertextuellen Vorzeichen: die Novelle wird in Bezug auf ihren wohl wichtigsten Intertext, auf Adalbert Stifters frühe Erzählung, Der Condor analysiert. Die vergleichende Analyse soll zeigen, wie die motivischen und narrativen Strukturen bei Nádas moduliert, neu geschrieben und problematisiert werden. Das Hauptmerkmal fällt dabei auf die Veränderungen der optischen Motivik, die bei Stifter noch durch die symbolhaften Himmelskörper, Mond bzw. Sonne gelenkt werden. Die schöne Geschichte der Fotografie übernimmt diese Symbolik, ergänzt sie jedoch mit der fotografischen Technik, sowie mit den „inneren” Bildern der vom Wahnsinn gedrohten Protagonistin - beide als potenzielle Dispositive bzw. Problematisierungen der Stifterschen Lichtmetaphorik.

\footnotetext{
${ }^{53}$ Uo., 99, 169.

${ }^{54}$ Lásd pl. Emlékiratok könyve I. 7. (a Szabálytalanságom szépségei címü fejezet), valamint a „szép” hangsúlyos említését a falikép-fejezetben (Uo., 353.), illetve a Gyllenborg-fénykép „szépségéröl” szóló passzust (Uo., II. 284.), valamint BALASSA, i. m., 474.
} 